\title{
Teorie světové literatury na XXII. kongresu ICLA/ AILC v Macau
}

\author{
Anton Pokrivčák (Trnava) - Miloš Zelenka (České Budějovice)
}

\begin{abstract}
Abstrakt
Studie analyzuje průběh a výsledky XXII. kongresu ICLAVAILC realizovaného pod názvem Literature of the World and the Future Comparative Literatury ve dnech 29. 7. - 2. 8. 2019 ve východoasijském Macau. Kongres potvrdil ústup od amerického konceptu světové literatury vnímané jako zážitkový způsob čtení realizovaný formou prekladu. Pojem „iteratura světa“ byl více frekventován než tradiční pojem světová literatura (H. Saussy), implikující větší homogenitu a standardizovanost kánonu velkých děl, zatímco termín „literatura světa“ vystupuje méně elitářsky. Zaměření na vztahy a procesy v podobě „sití“ a „map“ relativizuje dosavadní modely světové literatury a vytváři předpoklady pro její nové studium. Názor, že na (světovou) literaturu není možné se dívat jen z jednoho kulturního či teoretického pohledu, prolínal nejen kongresová jednání, ale i česko-slovenské číslo časopisu World Literature Studies s názvem Image of remot countries in the literatures of Central and Eastern Europe.
\end{abstract}

\section{Klíčová slova}

XXII. kongres ICLAVAILC; komparatistika; světová literatura; „literatura světa“; teorie překladu; postkolonialismus a interkulturní imagologie

\section{Abstract \\ Theory of Literature World at XXII Congres ICLA/AILC in Macau}

The study is an analysis of the procedure and results of the XXII. Congress of the ICLAVAILC Literature of the World and the Future of Comparative Literature which took place between July 29 and August 2, 2019 in the East Asian Macau. Instead of a more traditional concept of "world literature" (H. Saussy), which implies a greater homogeneity and standardisation of the canon of great works, the concept of "literature of the world", considered as less elitist, was more frequently used in both lectures, workshops as well as informal talks among the participants. The emphasis on relations and processes in the form of "networks" and "maps" has a relativizing effect on the existing models of world literature, creating conditions for its study. The idea that the (world) literature cannot be approached only from one cultural or theoretical point of view permeated not only the discussions at the congress, but also the joint Czecho-Slovak issue of the journal World Literature Studies entitled The Image of Remote Countries in the Literatures of Central and Eastern Europe.

Tento článek je upravenou a doplněnou verzi studie Literature of the World and the Future of Comparative Literature of Perspective XXII Congres ICLA/AILC publikované ve World Literature Studies 11, 2019, č. 4. Článek zveřejňujeme vzhledem $\mathrm{k}$ tomu, že autoři tohoto textu vedle A. Zelenkové byli jedinými zástupci česko-slovenské komparatistiky na kongresu v Macau, a tudiž tento článek je jedinou informací o této události v českém kontextu. 


\section{Key words}

XXII. Congress of the ICLAVAILC; comparative literature; world literature; "literature of the world"; theory of translation; postcolonialism and intercultural imagology

Když Libuša Vajdová referovala do časopisu World Literature Studies o předchozích komparatistických kongresech probíhajících pod záštitou Mezinárodní asociace pro srovnávací literaturu (ICLA/AILC), příznačně svůj článek nazvala Je komparatistika mŕtva??1. Jednalo se o parafrázi skeptického výroku Susan Bassnett z příručky Comparative Literature. A Critical Introduction ${ }^{2}$ formulující přirozené obavy z permanentní dekonstrukce předmětu a metod srovnávacích studií, které své výzkumné jádro rozpouštěly v příbuzných disciplínách. Jestliže Paříž 2013 svou pozornost soustředila na studium překladu jako relevantního zdroje mezikulturní komparace a literární vědy vůbec, Vídeň 2016 znamenala návrat komparatistiky k literatuře a jazyku, k evropským tradicím a minulosti této tradiční disciplíny. ${ }^{3} \mathrm{Z}$ tohoto zorného úhlu pohledu můžeme XXII. mezinárodní kongres ICLA/AILC v Macau realizovaný pod názvem Literature of the World and the Future of Comparative Literature ve dnech 29. 7. - 2. 8. 2019 označit za průlomový, nebot potvrdil, že hledání rozmanitých modelů a podob světové literatury má své opodstatnění a reálnou badatelskou perspektivu a že srovnávací literární věda nedisponuje jedním způsobem a typem výzkumu. Kongres zároveň zdůraznil známou skutečnost, že teoretický a metodologický diskurs probíhá v různých jazycích a v rozmanitých mocenských vztazích. Jakoby tato optimistická vize komparatistické budoucnosti upřednostňující před striktně regulativními idejemi široké pole hodnotových reflexí spjatých aspektem „komparování“, nenavazovala na závěrečný, shrnující panel kongresu ve Vídni s názvem Theory of World Literature and the Politic of Translation, kde hlavní př́íspěvky přednesli mediálně známí američtí komparatisté David Damrosch a Emily Apter z New Yorku a Harvardu. Právě posledně jmenovaná ve své přednášce odkázala na svou publikaci Against World Literature: On the Politic of Utranslability ${ }^{4}$, v níž studium světové literatury, stejně jako italský komparatista Franco Moretti ${ }^{5}$ považuje vzhledem k pluralitě a neujasněnosti objektu výzkumu a jazykové rozdrobenosti za problém, který je neřešitelný v kontextu samotné literární vědy. Přihlášení se k ideji „světové literární republiky“ jako virtuální „meziliterární sítě“ bez hranic a bariér, jak uvádí francouzská badatelka Pascale Casanova ${ }^{6}$, však znamenalo i v př́ípadě Apter kritiku konceptu univerzální literatury jako ustáleného korpusu textů překračující národní, politické a lingvistické horizonty. Obdobně David

1 VAJDOVÁ, Libuša: Je komparatistika mŕtva? (Nové postavenie prekladu v skúmani literatúr a kultúr). World Literature Studies 5 (22), 2013, č. 4, s. 72-86.

2 BASSNETT, Susan: Comparative Literature. A Critical Introduction. New York: Willey - Blackwell, 1993, s. 43 .

3 VAJDOVÁ, Libuša: Návrat komparatistiky k literatúre a jazyku. World Literature Studies 8, 2016, č. 4, s. 107111.

4 APTER, Emily: Against World Literature. On the Politics of Utranslability. London and New York: Verso Books, 2013.

5 MORETTI, Franco: Conjectures on World Literature. New Left Reviev 1, 2000, s. 54-68.

6 CASANOVA, Pascale: La République mondiale des Lettres. Paris: Édition du Seuil, 1999. 
Damrosch proslavený v anglosaském kontextu prací What is World Literature? ${ }^{7}$ svou přednášku zahájil exkursem do dějin teoretického myšlení a světové literatury, kam zahrnul vedle redukovaného euroamerického kontextu Orient a Latinskou Ameriku. Zcela však nepochopitelně opominul slovanskou komparatistiku ze střední, východní a jihovýchodní Evropy. Ačkoli název jeho knihy př́mo odkazuje na Ďurišinovu monografii Čo je svetová literatúra?, nenalezneme zde jedinou zmínku či citaci, což platí i pro českou, ruskou, polskou, bulharskou, slovinskou ad. komparatistiku. Paradoxně se zde neobjeví ani rakouský komparatista srbského původu Zoran Konstantinović se svou v německy mluvícím prostředí rezonující publikací Welttiteratur. Structure, Modelle, Systeme $e^{9}$. Na rozdíl od Emily Apter Damrosch vidí světovou literaturu jako eliptickou refrakci národních literatur, jako text, který překladem získává, a zároveň nikoli jako pevný kánon, ale jako specifický typ čtení založený na recepčním zážitku ze světa mimo našeho času a prostoru.

Jestliže jsme upozornili na určitou koncepční i kontextovou diskontinuitu jednání v Macau s předchozími kongresy, pak toto tvrzení platí zejména pro úvahy o světové literatuře, které se staly ústřední tematickou osou většiny relevantních př́spěvků. Už samotný název implikoval skutečnost, že světovou literaturu netřeba apriori odmítat či negovat, pokud její status a následná interpretace nekoreluje s konkrétním diskursem. Totéž platí i pro budoucnost literární komparatistiky, jejižz dosah a metody se rozličně praktikují v různých krajinách. Typické je proto vedle volání po nových teoriích i prefigurace a cirkulace komparatistických pojmů v čase a prostoru, kdy se např. tradiční termíny objevují v novém prostředí determinovaném specifičností lokálních či regionálních tradic. Pokud bychom měli taxativně vymezit některé podstatné momenty sjezdu v Macau, byl to především ústup od amerického konceptu světové literatury vnímané jako specifický zážitkový způsob čtení vytvořený v naší mysli cirkulací a recepcí literárních textů realizovaných formou překladu. Vůbec prrítomnost problematiky překladu, tj. traduktologie, jak ji označovali na sjezdu v Paříži francouzští komparatisté, nebyla i ve srovnání s Vídní 2016 tak intenzivní. Překlad zůstává jako univerzální nástroj výzkumu kultury, nikoli však základní a jediný: je spíše zprostředkovanou, „označující“ formou, ne však vlastní podstatou světové literatury chápané jako metodologicky uchopitelná kategorie. Na druhou stranu není možné nahradit klasickou literární komparatistiku studiem světové literatury, jak se to děje běžně na mnohých amerických univerzitách. Dorothy M. Figueira v této souvislosti ironicky hovoří o nové inkarnaci pentagonské konstrukce areálových studií, kdy „Pod maskou demokratizácie a odklonu od údajného «elitarizmu» literárnej komparatistiky teoretici a teoretičky svetovej literatúry turdia, že vedú seriózny dialóg so svetom, ale iba ak tento svet hovori anglicky alebo je preložený do angličtiny". ${ }^{10}$ Navzdory tomuto limitu kongres potvrdil skutečnost, že o světové literatuře je možné uvažovat i teoreticky, prostřednictvím či pojmů a termínů, které jsou sice sémanticky mnohoznačné, přesto se pohybují i se svými lokálními konotacemi v konkrétním epistemologickém rámci.

7 DAMROSCH, David: What is World Literature? Princeton: Princeton University Press, 2003.

8 ĎURIŠIN, Dionýz: Čo je svetová literatúra? Bratislava: Obzor, 1992.

9 KONSTANTINOVIĆ, Zoran: Weltliteratur. Structure, Modelle, Systeme. Freiburg: Herder, 1979.

10 FIGUEIRA, Dorothy M.: Prehodnotenia etiky porovnávania. World Literature Studies 11, 2019 , č. 1, s. 71. 
Na kongresu se vynořila i otázka vymezení funkce a prognóz srovnávací literatury, která by si měla uchovat své autochtonní jádro, zároveň přesahovat i do jiných, třeba i exaktních věd. Druhý aspekt budoucnosti komparatistiky lze spatřovat v radikálnějším dekonstruování euroamerického pohledu na texty aspirující na „světovost“, tj. v teritoriálním, geopolitickém nebo lingvisticko-etnickém transferu z tradičních kontinentů (Evropa a Amerika) do jiných světadílů. Existují rozdíly v teoretickém myšlení o srovnávací literatuře nejen mezi Evropou a Amerikou, ale i jiné subjekty jako Jižní Amerika, Pákistán, Indie, Japonsko a zejména Čína si logicky vynucují odlišné koncepty světovosti a světové literatury, pro které je zřejmé, že terminologické ekvivalenty s proměnlivým sémantickým obsahem nemusejí být hodnotovými synonymy. Zároveň se zde ukazuje, že zde neplatí třeba tradiční francouzské Van Tieghemovo pojetí literatury srovnané a srovnávací, tak i nejnovější americká představa světovosti jako virtuální sítě textů přeložených do angličtiny, kdy každé nové čtení, jak tvrdí H. Saussy, je v podstatě již dalším překladem ${ }^{11}$. Proto zde vzniká otázka, zda světová literatura se realizuje jako univerzální či jako globální, planetární, transnacionální, aniž bychom přesně dopředu věděli, co tyto pojmy znamenají. Základní termíny jako světovost, multikulturalismus, kosmopolitismus, postkolonialismus, národní literatura, migrace, meziliterárnost, exotizace, zdomácnění ad. odlišně zastarávají anebo se rozmanitým způsobem inovují v různých světadílech. $\mathrm{S}$ tím souvisí i problém, že $\mathrm{k}$ dispozici není závazný typ komparatistického výzkumu s kanonizovanou metodou a předmětem zkoumání a že komparatistika stejně jako celá literární věda má narativní charakter. Otázka proto zní: je třeba se vracet k redefinování podstaty světové literatury a permanentně se ptát po jejím vymezení, funkci a kolísajících hranic? Nevytváří si komparatistika své fikční světy a nepohybuje se spekulativním prostoru metajazyka a metatextu? Má vůbec smysl v tomto „mnohohlasí“, v prostoru, v němž konfrontujeme „ne-srovnatelné“, např. psát dějiny světové literatury, které jsou v podstatě kompilačním oborem vycházejícím pouze z dostupných překladů nejrůznějších textů do angličtiny? Z jednotlivých kongresových diskusí s odkazem na oficiální projekt ICLA/ AILC editorů J. Neubauera a M. Cornise-Popea History of the Literary Cultures of East-Central Europe Junctures and Disjunctures in the 18th and 20th Centuries I-IV $V^{12}$ také vyplynulo, že tradiční dějiny světové literatury jsou sice psány „mezinárodně“, ale v zásadě formou národních dějin vztaženou, prolongovanou k jiným teritoriím a analyzující na principu racionálního binarismu interakce mezi jednotlivými literaturami. Volání po jakémsi „relačním“ či „transnacionálním“ charakteru světových dějin by mělo překonávat tradiční protiklad mezi „domácím“ a „cizím“ a soustředit se vedle hledání obecných vzorů a zákonitostí vývoje i na jedinečnost tématu či problému v „nenárodni“ perspektivě. Podstatu dějin světové literatury proto je možné odvozovat ze studia meziliterárního a mezikulturního procesu v jeho prostorových a vztahových rámcích, nikoli v předdefinovaných národních kategoriích a jednotkách. Zaměření na vztahy a procesy v podobě „síti““ a „map“

11 SAUSSY, Haun: Comparative Literature in an Era of Globalization? Chicago: Johns Hopkins University Press, 2004.

12 NEUBAUER, John - CORNIS-POPE, Marcel (eds.): History of the Literary Cultures of East-Central Europe Junctures and Disjunctures in the 19th and 20th Centuries I-IV. Amsterdam - Philadelphia: John Benjamins Publishing Company, 2004-2010. 
musí relativizovat dosavadní modely světové literatury a vytvářet předpoklady pro její studium v její sémantické mnohoznačnosti a syntaktické variabilitě.

Místo pořádání XXII. kongresu v Macau, v bývalé portugalské kolonii, která dnes představuje autonomní oblast Č́ny, nebylo vybráno náhodně. Již v roce 2004, tj. sedm let po odevzdání této původně britské kolonie do čínských rukou, byl kongres lokalizován do blízkého Hongkongu. V obou případech toto umístění vyjadřovalo mocenskou dominanci jednotné Č́ny v politice, ekonomice, ale i ve vědě a v podstatě navozovalo dojem jakéhosi „kongresu v kongresu“. Pořadatelé účastníkům oficiálně nabídli za zlevněnou cenu ubytování v luxusním hotelu Parisien Macau, kde se mělo konat slavnostní zahájení $\mathrm{i} u$ ukončení kongresu. $\mathrm{V}$ předvečer sjezdu však veškeré jednání byla náhle přenesena do místního univerzitního komplexu postaveného v polovině osmdesátých let minulého století. V pozadí tohoto rozhodnutí byly argumenty americké delegace, která upozorňovala na fakt, že pro intelektuálně naladěné akademiky by bylo nevhodné debatovat o srovnávací literatuře $\mathrm{v}$ sálech rozprostírajících se nad světoznámým kasinem umístěným v hotelovém přízemí. Překvapilo rovněž, že čínští pořadatelé kongresu vyhradili pouze týden, avšak vzhledem $\mathrm{k}$ vysoké teplotě a vlhkosti ovzduší tuto skutečnost komparatisté zhruba ze sedmdesáti zemí posléze sympaticky kvitovali. Už proto, že v poslední červencový den se nečekaně ohlásil tajfun a hrozilo nebezpečí, že další jednání vůbec neproběhnou. Čínští pořadatelé však mistrovsky zvládli evakuaci účastníků, z nichž byly nejdříve upřednostněny ženy-badatelky, narychlo zajištěnými autobusy do blízkých hotelů. Naštěstí tajfun oklasifikovaný stupněm 8 z možných 10 Macau minul zhruba ve vzdálenosti $250 \mathrm{~km}$, a tak závěrečné referáty mohly pokračovat. Výrok slovinského badatele M. Juvana, který si posteskl, že cestoval $10000 \mathrm{~km}$ ve dvou dnech, platil drahou letenku a hotel, a poté by údajně nemohl přednést ani krátký referát, dokresloval obavy některých komparatistů uzavřených v hotelových komplexích.

Třeba zdůraznit, že místní pořadatelé kongres, na němž nakonec odezněly všechny referáty, zajistili na výbornou nejen administrativně, ale i obsahově. Čínská komparatistika v posledním dvacetiletí na kongresech ICLA/AILC totiž dominovala počty účastníků, svými tématy a panely a obratností zákulisní politiky, která přinesla řadě čínských badatelů úspěšnou nominaci do exekutivních orgánů. Č́nští komparatisté, z nichž profesor Longxi Zhang z Hongkongu přednášející i na Harvardu, vykonával v letech 2016-2019 funkci předsedy Mezinárodní asociace komparatistư ${ }^{13}$. Pod patronací Č́nské asociace komparatistů založené v roce 1985 se sekretariátem na Ústavu srovnávacích literatur a srovnávacích kultur Univerzity v Pekingu, v jejímž čele stojí prof. Wang Ning ze Sanghai Jio Tong University vycházející následující specializované prestižní časopisy jako Comparative Literature in China (Shanghai International Studies University), International Comparative Literature (Shanghai Normal University) a Comparative Literature and World Literature (Peking University Press). Kongresové jednání probíhalo v angličtině a zejména v čínštině, občas zazněla ještě i úřední portugalština a tradiční jazyk komparatistů francouzština. Běžně se však stávalo, že celé jednotlivé panely se profilovaly v čínštině jako ryze „národní" s regionálními tématy s upozorněním, že anglicky komunikující

13 LONGXI, Zhang: From Comparism to World Literature? New York: SUNY Press, 2015. 
badatelé nebudou přednášce a diskusi schopni porozumět. „Čínský“ ráz XXII. kongresu podtrhovala i skutečnost, že zasedání výkonného výboru asociace se konalo ve dnech 25.-27. 7. 2019 v blízkém, již ve vnitřní Číně se nacházejícím Shenzhenu.

Ústřední myšlenka kongresu Literatura světa a budoucnost srovnávací literatury byla rozdělena do patnácti tematických okruhů: 1 . Konverzace napříč rozdíly, 2. Rozličné jazyky srovnávání, 3. Literární, kulturní a temporální (ne)přeložitelnost, 4. Četné historie srovnávací literatury, 5. Kánony, žánry a média, 6 . Interdisciplinarita ve srovnávací literatuře, 7. Teorie literárnosti např́íc kulturami, 8. Světová literatura a Čína, 9. Globální humanitní vědy z perspektivy Východu, 10. Internacionalizace čínské literární vědy, 11. Imigrantská literatura, 12. Oběh informací ve východní Asii: žurnalismus, próza a elektronická textualita, 13. „Sinofónní“ jako anti-diskurs, 14. Memoárová literatura ve východní Asii v období modernismu a 15. Fascinace mezinárodními literárními cenami: pro koho je cena důležitá? $\mathrm{Z}$ nich více než jedna třetina, jak jest z tohoto výčtu zřejmé, byla zasažena čínským „vlivem“. Ještě větší nadvláda mocenské sféry čínské komparatistiky proběhla v 34 workshopech a okrouhlých stolech, kde téměř více než polovina témat měla ve formulaci názvu bud” „čínský“ nebo „východoasijský“.

Kongresy komparatistů, u jejichž vzniku stál v polovině 20. století americký vědec českého původu, člen Pražského lingvistického kroužku René Wellek (I. kongres se konal roku 1955 v Benátkách) patř́i bezesporu k nejreprezentativnějším přehlídkám stavu a metod literárně-teoretického myšlení a účast na nich organizovaných v pravidelných tř́letých intervalech bývá $\mathrm{v}$ př́padě akceptace přihlášek považována za vysoce prestižní badatelskou záležitost. ${ }^{14} \mathrm{O}$ to více byla zarážející neúčast českých a slovenských badatelů z akademických a univerzitních pracovišt. Ačkoli se na tomto faktu nepř́iznivě odrazila velká vzdálenost od Evropy, přesto definitivní potvrzení a přijetí Česko-slovenské asociace komparatistů vedené Róbertem Gáfrikem umožňovalo přednostní a bezproblémovou účast na kongresu v Macau. O to více potěšilo zvolení středoevropských komparatistů, předsedů národních asociací, vytvářejících symbolický slovanský „miniblok“, za členy výboru Mezinárodní asociace pro srovnávací literaturu (R. Gáfrik - Česká a Slovenská republika, A. F. Kola - Polsko a M. Juvan - Slovinsko). Za česko-slovenskou stranu na kongresu zazněl společný příspěvek Anny Zelenkové a Silvie Pokrivčákové Some comparatist notes on the categories of "the national" vs. "the world", "the historical" vs. „the present", "one's own" vs. "foreign" (Několik komparatistických poznámek ke kategoriím „národni" vs. „svètovy““, „historicky““ vs. „současny““, „vlastni“ vs. „,izi“), v němž se autorky prostřednictvím dvou slovenských próz - Faustiáda (1864) od J. Záborského a P. Vilikovského Večně je zelený... (1989) - pokusily zachytit určité vývojové trendy ve vnímání „cizího, jiného“ a s ním související stereotypy, mýty, předsudky a klišé v satirickém literárním textu, který v podobě „meziliterární sítě“ lze chápat jako problematický „př́iběh“ s četnými paralelami, zlomovými body a „bílými místy“.

Na sjezdovém jednání rovněž participovali Anton Pokrivčák za Slovensko a Miloš Zelenka za Českou republiku, kteří jako editoři sestavili monografické číslo World Literature Studies pod názvem Images of Remote Countries in the literature of Central and Eas-

14 ZELENKA, Miloš: XX. světový komparatistický kongres. Slavica litteraria X 16, 2013, č. 1-2, s. 241-243. 
tern Europe dedikované jako společný př́íspěvek Česko-slovenské asociace komparatistů sjezdovému rokování v Macau, který se pokusil o vymezení metodologických pohledů na interkultúrnu problematiku z interkontinentální perspektivy. Zároveň připravili společný referát Image of remote countries in the literatures of Central and Eastern Europe: On the theoretical starting points of intercultural comparative studies. ${ }^{15}$ Editoři při jeho koncipování metodologicky vyšli z teorie mezikulturnosti a komparativní imagologie, které v současnosti modifikují tradiční zkoumání East-West Studies směrem ke srovnávací interkontinentální literární vědě jako $\mathrm{k}$ jisté hodnotové normě uvažování o mnohonárodní literatuře vůbec. Tento epistemologický rámec pak může přispět k odideologizovanému chápání kulturní ,jinakosti“ traktované v širokých univerzálních souvislostech. Nejde tu jen poznání exotických toposů vzdálených a „ne-podobných“ textů, ale především o hlubší pochopení střední a východní Evropy. Ta totiž se svými geograficko-kulturními areály představuje sociokulturní systémy s velkou mírou exogenních procesů, kde se formujî specifické kulturní konstrukce, obrazy identity a jinakosti. Impulsy Západu a zejména Východu zde vždy působily v modifikované podobě, nebot̉ zprostředkovatelská funkce kulturní hodnoty měla „sebereferenční“ charakter, a proto byla prostředkem národní identity, prostředkem cesty ke státní a národnostní suverenitě. Editoři, kteří při výběru upřednostnili texty analytické, problémové a teoreticky invenční vycházející ze základního výzkumu, si kladli za cíl zjištění, jak obraz vzdálených krajin a kultur je reflektován ve středoevropském a východoevropském literárněkritickém diskurzu a též nakolik obraz radikálně ,jiného“ je schopen tento diskurs, např. jeho sémantiku a terminologii, měnit. Jinak řečeno, zda lze realizovat transfer např. imagologických konceptů historicky vytvořených v jistém kontextu do typologicky a strukturně odlišného kulturního areálu. Se zachycením etnické, biologické či materiální rozdílnosti - zejména v binární opozici „metropole“ $\mathrm{x}$ „kolonie“, at už v minulých stoletích nebo v postmoderních podmínkách globalizovaného provincialismu - souvisí i revize kritických postupů dominujících v tzv. západní literární vědě, tzn. permanentně si klást otázku o smysluplnosti obhajoby či odmítání ideologických principů orientalismu, post(de)koloniálních studií, kulturních a sociálních studií, dekonstruktivismu, komparativní imagologie, teorie mezikulturnosti od jako jistých selektivních forem výzkumu složitého a mnohovrstevnatého fenoménu světová literatura. Česko-slovenské monografické číslo World Literature Studies, které ocenili komparatisté jako Peter Hajdu, Haun Saussy, Theo D’haen, bylo distribuováno mezi jednotlivé účastníky kongresu.

Pokud jde o další př́spěvky, omezíme se pouze na ty, na jejichž základě lze vyvodit určité obecnější závěry o duchu tohoto kongresu, protože vzhledem na jeho rozsáhlost (přibližně 2000 účastníků) a variabilitu tematického záběru, není možné analyzovat všechny zajímavé detaily. Jak už bylo uvedeno, zřejmě nejpřesvědčivějším dojmem, který bylo možné na kongresu identifikovat ve většině přednášek a referátů, byla určitá snaha jednotlivých literatur a kultur, diferencovaných podle národní, etnické nebo rodové báze, situovat se do prostoru literatury světa. Je zajímavé, že pojem „literatura světa“ měl na kongresu o mnoho větší frekventovanost (objevil se i v názvu kongresu), než tradič-

15 POKRIVČÁK, Anton - ZELENKA, Miloš (eds.): Image of Remote Countries in the Literatures of Central and Easter Europe. World Literature Studies 11, 2019, č. 2, s. 3-15. 
ní pojem světové literatury. Pravděpodobně to souvisí s faktem, že „světová literatura“ implikuje intenzivnější homogenitu, představu určitého standardizovaného kánonu velkých děl, který v současném myšlení o srovnávací literatuře „vychází z módy“, zatímco pojem literatura světa je méně elitářským. Projevilo se to už v hlavní plenární přednášce hned první den kongresu, když Saun Haussy hovořil o literatuře s hranicemi a bez hranic („Literature With and Without Borders“) a poukázal na jistou omezenost, pokud se díváme na literaturu jen z jednoho kulturního anebo teoretického pohledu. Literární vědci se podle něho ze zvyku zabývají jen určitou skupinou teoretiků, žánrů či konceptů a zapomínají na skutečnost, že v jiných kulturních podmínkách existují další teoretici, koncepty a žánry s jiným obsahem. Tak jako v biologii vědci pracují s tzv. „modelovými“ organismy, v literární vědě máme podle Saussyho též takového „modelové organismy“. ${ }^{16}$ Jestliže však v biologii model neznamená univerzálnost, ale spíše očekávání heterogenity, tedy více jiných modelů, mělo by tomu tak být i v literární vědě. Proto, hovoříme-li o epice nebo tragédii, neznamená to, že jejich modelové rozpracování Aristotelem je jediné a univerzální. Jak uvidíme dále, tyto pojmy mají jinou náplň např. v čínské nebo v dalších literaturách. Podobné je to nap̌r. s kategorií románu, jehož definici vypracovanou na základě evropských kritérií narušuje např. Tale of Genji. Co vše toto znamená pro literární komparatistiku, jestliže máme na mysli její budoucnost? Čtenářskou a teoretickou rozdrobenost? Určitě ne, spíše výzvu pro další výzkumnou snahu přetavit jednotlivosti do něčeho, co je přesahuje do světové literatury. Tu je potřebné podotknout, že bez světové literatury by komparativní literatura byla ochuzena, ztratila by svoje přirozené směřování k čemusi nadnárodnímu, nadetnickému. Přirozeně i na světovou literaturu můžeme nazírat z vícerých úhlů pohledu. Saussy tu dává do kontrastu Goetheho pojem „Weltliteratur“, s evropskou a německou kulturou v přirozeném centru, a Meltlzovu koncepci jako př́ílad demokratizace světové literatury.

Přehodnocování a problematice zaužívaného př́stupu ke komparativní literatuře, a v konečném důsledky i podstaty „světovosti“ ve světové literatuře, se objevuje i vícerých jiných tematických celcích a workshopech. V tematickém bloku Teoretizováni literárnosti napríč kulturami Herrad Heselhausová z University of Tsukuba se ve svém příspěvku soustř̌eduje na tzv. „vztahová studia“ (relational studies), tj. na přístup, který zdůrazňuje holistický přístup zažití literárního textu na úkor tradiční objektivizace součástí literárního procesu a interpretaci literárního díla výlučně z hlediska textu, kontextu nebo čtenáře. Tradiční teoretický záběr vztahových studií Heselhausová aplikovala na vyučování literatury např́ić rozličnými kulturami, tj. snažila se poukázat na heterogenitu osobnostního vnímání literatury determinovaného rozdílným zážitkovým komplexem čtenáře. Akcent jinakosti ve vztahu ke smyslu literárnosti se objevil i v dalších referátech zařazených do tohoto tematického celku včetně už vzpomenutého našeho příspěvku. Pokud Anders Pettersson např́íklad ještě mluvil v obecnější rovině o konceptualizaci rozdílnosti literárních jevů, Adia Mendelson Maoz analyzovala izraelské reprezentace palestinské jinakosti a Jayshree Singh poukázala na rozdílnosti ve vnímání subjektu a svobody v západní a východní poetice.

16 SAUSSY, Haun: Comparative Literature in an Era of Globalization? Chicago: Johns Hopkins University Press, 2004. 
V tematickém bloku Četné historie komparativni literatury Chengzhou He ve vystoupení symptomaticky nazvaném Jak dèlat věci s dramatem: srovnávaci přistup $k$ dějinám činského dramatu 20. století (určitě aluze na slavné dílo Johna Austina How to Do Things with Words) poukázal na odlišnosti v chápání symbolismu a realismu věcí mezi evropskou a čínskou estetikou. Inovativní př́stup k něčemu takovému tradičnímu, jako je literární období, charakterizovalo vystoupení Svenda Erika Larsena z Univerzity v Aarhusu v př́spěvku nazvaném Prostory realismu: myšlenky a strategie nového projektu realismu, do něhož je zapojeno množství zemí. Jeho cílem je přes prizma realismu jako evropského fenoménu s globálním dosahem nanovo číst lokální literatury v globální perspektivě, přehodnotit literatury s postkoloniální perspektivy, přehodnotit kulturní výměnu jako ne-hegemonistický proces a přehodnotit kontextualizaci literatur v širším mediálním prostoru. Larsen podotýká, že realismus není zobrazením reality, ale její experimentální rekonstrukcí prostřednictvím literárních strategií se zřetelem ku vlivu na čtenáře. Důležitým u realismu není jen něco, co je za textem (reference), v textu (reprezentace), ale i něco co je před textem (perspektiva čtenáře). Všechny tyto tři aspekty jsou podle Larsena důležité. $\mathrm{V} \mathrm{Ev-}$ ropě zažité koncepce, např. koncept literatury, světové literatury, jako i tradiční pojetí anglofonní literatury, zpochybnil i Stefan Helgesson v př́spěvku Poznámka k dekoloniálním konceptuálním dějinám literatury. Relevantním referátem $\mathrm{v}$ tomto tematickém bloku byl i pokus o nazírání na světové dějiny literatury z úhlu pohledu otroctví, který prezentovala Karen-Margrethe Simonsenová.

Mnohé workshopy se zabývaly i dalším významným fenoménem komparativní a světové literatury, tj. překladem. Jak už bylo připomenuto, překlad je v určitém smyslu základním předpokladem existence světové literatury, protože bez něho by nebylo možné rozpoznat četná významná díla. Protože nikdo neovládá všechny jazyky světa, některá díla musí být přeložena. Překlad však vyvolává i určité zásadní problémy. Vytváří nerovnoměrnost vzhledem na světovost, a tudíž důležitost některých jazyků a lokálnost jiných. Pascale Casanova např. ve svém slavném díle La République mondiale des Lettres tvrdí, že světovost a univerzálnost literatury byla zhmotněna ve francouzském jazyce a v Paříži, v literárním hlavním městě světa, v němž žilo mnoho autorů. ${ }^{17}$ Pařriž se stala bránou $\mathrm{k}$ jejich úspěchu na mezinárodní scéně, na kterou vstoupili prostřednictvím důležitého faktoru překladem svých prací, do jednoho z vícerých hlavních „literárních“ jazyků. Při přeložených dílech se ale vynořuje i otázka zachování estetických kvalit originálu, nepatřičných sémantických posunů apod. Podle Damrosche netřeba odsuzovat posuny v překladu, ale akceptovat je jako nevyhnutelné a obohacující pro dané kultury a jazyky, jakož i vzhledem na možnost odkrýt hloubku významu díla jeho interpretací v národním a světovém kontextu. Jinak řečeno: jestliže něco ztratíme hloubkou a kvalitou, lze to nahradit rozsahem a distancí. ${ }^{18} \mathrm{Na}$ kongresu byly uvedené problémy konfrontovány zejména ve workshopech zkoumajících překlady mezi kulturně a etnicky vzdálenými jazyky, s indikací vztahu mezi uměleckými translačními metodami a kulturními identitami vznikajícími v procesu transkulturního přenosu.

17 CASANOVA, Pascale: La République mondiale des Lettres. Paris: Édition du Seuil, 1999.

18 DAMROSCH, David: What is World Literature? Princeton: Princeton University Press, 2003. 
Na závěr můžeme konstatovat, že navzdory tomu, že ve vztahu k Evropě se kongres konal téměř na opačném konci světa, byl i blízký svou inkluzivností, tudíž snahou prezentovat jednotlivé kultury a literatury jako součást většího celku. Symbolicky to vyjádřil v zahajující řeči Zhang Longxi, dosavadní prezident ICLA, cituje čínského filozofa Konfucia: „Neni velkou radostí mít prátele, kteři přicházejí zdaleka?" Jako následující místo budoucího sjezdu byla zvažována gruzínská kandidatura Univerzity v Tbilisi, která byla jako jediná oficiálně podána, avšak gruzínští komparatisté paradoxně v Macau chyběli, a tak nemohli svůj návrh osobně podpořit. Nadějnější se však jevila americká nabídka na pořádání kongresu na Univerzitě v Princetonu, jejíž zástupkyně prof. Sandra Bermann byla nejen přítomna, ale i jednomyslně zvolena za nového předsedu Mezinárodní asociace pro srovnávací literaturu.

\section{prof. PhDr. Anton Pokrivčák, PhD.}

Katedra anglického jazyka a literatúry

Pedagogická fakulta, Trnavská univerzita

Priemyselná 4, 91843 Trnava, Slovensko

anton.pokrivcak@truni.sk

\section{prof. PhDr. Miloš Zelenka, DrSc.}

Katedra slovanských jazyků a literatur

Pedagogická fakulta, Jihočeská univerzita

Jeronýmova 10, 37115 České Budějovice, Česká republika

zelenka@pf.jcu.cz 